\title{
Paraoesophageal omental hernia
}

\author{
Maximilian Stephens, ${ }^{1}$ Andrew Hughes ${ }^{2}$
}

'University of Queensland, Brisbane, Queensland, Australia

${ }^{2}$ The Prince Charles Hospital, Brisbane, Queensland, Australia

\section{Correspondence to} Maximilian Stephens, maximilian.stephens@ uqconnect.edu.au
To cite: Stephens $\mathrm{M}$, Hughes A. BMJ Case Rep Published online: [please include Day Month Year] doi:10.1136/bcr-2013 009683

\section{DESCRIPTION}

A 61-year-old man with recently diagnosed gastrooesophageal reflux disease re-presented to his primary care physician due to persisting epigastric and pharyngeal pain refractory to maximal proton pump inhibitor therapy. Examination was unremarkable. Endoscopy with biopsy showed features of resolving gastritis. CT at another institution revealed a mediastinal mass originally reported as a lipoma or a well-differentiated liposarcoma, prompting his referral to our surgical unit. Initial chest radiographs revealed a retrocardiac mass (figure 1A). Follow-up arterial phase CT at our institution (figure 2A-C) more clearly demonstrated the transverse colon approaching the diaphragm and its omental attachment streaming through a hiatal defect. The omentum was characterised by several vessels, an important feature of omental hernias, but not lipomas or liposarcomas. Although biopsy was considered, the CT findings obviated any concerns. Paraoesophageal omental hernias are rare and sometimes confused for mediastinal lipomas and liposarcomas, but have important radiological signs that distinguish them from these tumours. ${ }^{12}$ Correct diagnosis is important as it can prevent unnecessary and invasive investigations such as angiography, biopsy and thoracotomy. ${ }^{1-3}$ On review of the initial CT images, omental vessels, displacement of the transverse colon and a hiatal defect were visible. The patient underwent successful laparoscopic hiatal hernia repair with full resolution of his symptoms. Chest radiography performed 3 weeks postoperatively showed anatomical resolution (figure 1B). We remain sceptical that his hernia was the source of his symptoms, as previous cases reported in literature have been asymptomatic. ${ }^{1-3}$
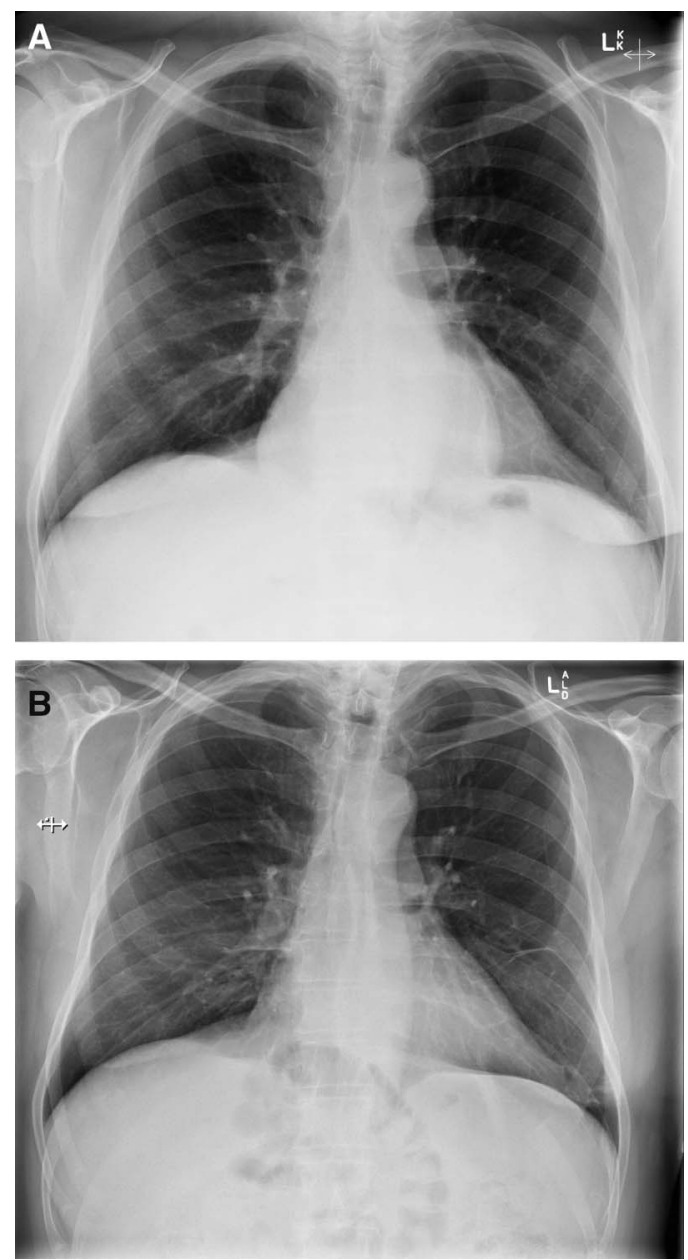

Figure 1 Chest radiography of a patient with paraoesophageal omental hernia. (A) Preoperatively there is a retrocardiac mass of lipomatous density with no gastric bubble. (B) Postoperatively there is anatomical resolution. 


\section{Learning points}

- Paraoesophageal omental hernias are rare and sometimes confused for lipomas and liposarcomas.

- Key radiological findings of omental hernias are omental vessels, superior/posterior displacement of the colon and a hiatal/diaphragmatic defect. Unenhanced CT may only show the latter two features.

- Unnecessary investigations can be avoided with correct diagnosis.
Contributors MS and AH have contributed significantly to the development of this manuscript in writing, literature review, concept design and review. MS undertook the most work and so this is reflected in the order of authorship.

\section{Competing interests None.}

Patient consent Obtained.

Provenance and peer review Not commissioned; externally peer reviewed.

\section{REFERENCES}

1 Maruyama R, Miyamoto T, Shoji F, et al. Intrathoracic omental herniation through the oesophageal hiatus in a young patient. Jpn J Thorac Cardiovasc Surg 2005:53:452-4.

2 Yunoki J, Ohteki $\mathrm{H}$, Naito $\mathrm{K}$, et al. Omental herniation through the esophageal hiatus mimics mediastinal lipomatous tumor. Jpn J Thorac Cardiovasc Surg. 2004;52:580-2.

3 Kabuta K, Ohara S, Yoshida S, et al. Intraothoracic omental herniation through the esophageal hiatus: a case report. Radiat Med 2001;19:307-11.

Copyright 2013 BMJ Publishing Group. All rights reserved. For permission to reuse any of this content visit http://group.bmj.com/group/rights-licensing/permissions.

BMJ Case Report Fellows may re-use this article for personal use and teaching without any further permission.

Become a Fellow of BMJ Case Reports today and you can:

- Submit as many cases as you like

- Enjoy fast sympathetic peer review and rapid publication of accepted articles

- Access all the published articles

- Re-use any of the published material for personal use and teaching without further permission

For information on Institutional Fellowships contact consortiasales@bmjgroup.com

Visit casereports.bmj.com for more articles like this and to become a Fellow 